Selcuk Journal of Agriculture and Food Sciences

http://sjafs.selcuk.edu.tr/sjafs/index

Research Article
SJAFS

(2020) 34 (3), 189-192

e-ISSN: 2458-8377

DOI:10.15316/SJAFS.2020.215

\title{
The Identification of Genetic Variation in Insulin-Like Growth Factors-I (IGF- I) Gene Region in Some Turkish Sheep Breeds**
}

\author{
Dustafa Tawfeeq ${ }^{1}$, (D) İsmail Keskin ${ }^{1}$, (D)Fatma İlhan ${ }^{1 *}$ \\ ${ }^{1}$ Selcuk University, Faculty of Agriculture, Department of Animal Science, Konya, Turkey
}

\begin{tabular}{l}
\hline ARTICLE INFO \\
\hline Article history: \\
Received date: 20.07 .2020 \\
Accepted date: 28.08 .2020 \\
Edited by: \\
İbrahim AYTEKIN; Selcuk University, \\
Turkey \\
\hline
\end{tabular}

\section{Keywords:}

Growth hormone

Insulin-like growth factor (IGF)

Sheep

Polymerase chain reaction (PCR

Restriction fragment length polymorphism (RFLP)

Sheep breeds

\begin{abstract}
ABSRACT
Insulin-like growth factors (IGFs) areknown as peptides with important metabolic effects required for cellular growth and metabolism. IGF-I is synthesized in liver tissue under the control of growth hormone $(\mathrm{GH})$ and released to blood. In the process of GH to accelerate growth, IGF-I occupies a large place. IGF-I clearly showed its important effects on the growth of animal studies. In this study, promoter region of the IGF-I gene were amplified by polymerase chain reaction (PCR) in sheep breeds (Akkaraman, Kivircik, Awassi, Sakiz, Daglic, Morkaraman, MalyaKarayaka (15 to 20 sheep per breed)) reared in Turkey. Informative restriction fragment length polymorphisms (RFLPs) were obtained with HaeII enzyme. The digestion of IGF-I gene with HaeII produced two alleles and three genotypes. Genotype frequencies were 59\%, 19\%and $22 \%$ for $\mathrm{AA}, \mathrm{BB}$ and $\mathrm{AB}$ genotypes, respectively. Allele frequencies were 0.70 for $\mathrm{A}$ allele and 0.30 for the $B$ allele. This study indicates the genetic profiles of the IGF-1 gene in native Turkish sheep breeds.
\end{abstract}

\section{Introduction}

To date, many hormones have been shown to be effective in growth physiology. It was discovered in the middle of the 20th century thatgrowth hormone (GH) enabled growth in mice (Kopchick et al., 2014). It was initially thought that growth hormone alone would provide growth, but studies have shown that it stimulates growth by stimulating peptide cell division called insulin-like growth factor (IGF) (Daughaday, 1997). It is now known that both hormones are effective in growing.

There are 2 forms of IGF; IGF-I and IGF-II, which are in the structure of the single- chain polypeptide (Le Roith et al., 2001). IGF-I is also called a somatomedin $\mathrm{C}$ and a basic polypeptide containing seven amino acids. IGF-II is a neutral polypeptide of sixty-seven amino acids. IGF-I amino acid sequence is $43 \%$ with proinsulin and IGF-II is $41 \%$ similar to proinsulin (Bondy et al., 1994). Polymorphism of IGF-I gene plays an important role in the regulation of IGF-I concentration, growth features (Ge et al., 2001; Y1lmaz et al., 2005; Behzadi et al., 2015; Grochowska et al., 2017) and many hormones (He et al., 2012).

\footnotetext{
* Corresponding author email: fatmailhan@selcuk.edu.tr

** Short communication
}

Studies conducted up to now have found that IGF alleles are associated with many yield characteristics such as birth weight, live weight gain, milk yield and fertility (Yilmaz et al., 2005; Pereira et al., 2005; Siadkowska et al., 2006; Li et al., 2008; He et al., 2012; Ali et al., 2016; Othman et al., 2016). IGF-I takes place in chromosome 3 in sheep and chromosome 5 in cattle and goats; and it contains 5 regions of exon (Alakilli, 2012).

Turkey's natural and economic conditions, agricultural structure and tradition, is suitable for sheep and goat breeding. (Kaymakci andEngindeniz,2010). However, sheep breeding has not shown adequate development. In Turkey, there is a shortage of meat production comparing to the nutritional requirements, and there is an increasing gap between meat products produced domestically and the amount consumed. It has even begun to import meat in recent times. Production improvements can be achieved by using new genetic technologiesandthe selection of heritable traits. IGF-I is acandidate gene for selection programmesthat can be done in terms of the meat production efficiency.

Insulin-like Growth Factor I (IGF-I) is a hormonelike polypeptide related to several economically important traits including growth and reproduction parameters in sheep. Due to the lack of knowledge about the genetic characterization and nucleotide sequence 
variations of the IGF-I gene in Turkey's sheep breeds, this study is aimed to detect the genetic polymorphism of IGF-I in different sheep breeds reared in Turkey.

\section{Materials and Methods}

In this study, eight different sheep breeds' $(\mathrm{N}=144)$ blood samples from different parts of Turkey are used. The sampling locations and provinces are given on the map of Turkey (Fig. 1). Genomic DNA was extracted from blood samples by the salting-out procedure (Miller et al., 1988). The purity and concentration of the isolated DNA were determined by electrophoresis in a $1 \%$ agarose gel and UV spectrophotometry.

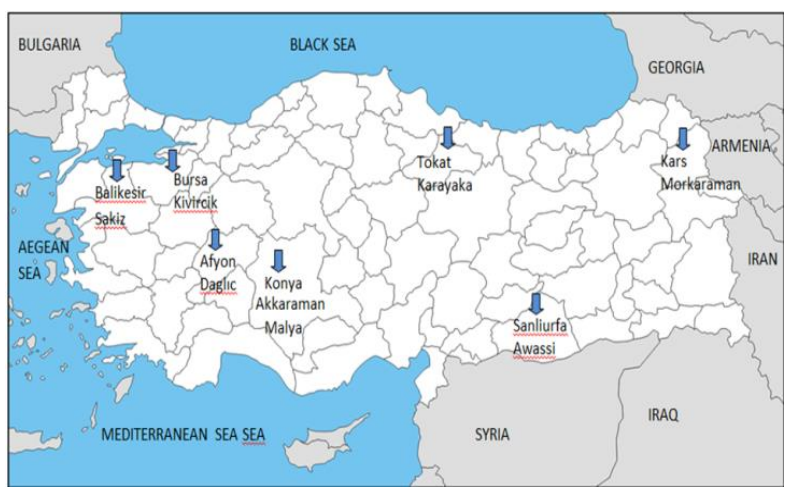

Figure 1

The location of the samples used for PCR-RFLP

The PCR reaction for the amplification of the promoter region of the IGF-I gene (265 bp was given by Yilmaz et al. (2005). The PCR reaction was as follows; $2 \mu \mathrm{L} 10 \mathrm{X}$ PCR buffer, $3 \mathrm{mM} \mathrm{MgCl} 2,3 \mathrm{mMdNTP}, 0.5$ $\mu \mathrm{M}$ primer, $0.2 \mathrm{U}$ Taq DNA polymerase. Primer sequences were: forward 5'ATTACAAAGCTGCCTGCCCC-3' and reverse 5'TCACATCTGCTAATACACCTTACCCG-3'. The PCR cycleinclude; initial denaturation at $94{ }^{\circ} \mathrm{C}$ for 5 min, 30 cycles of $94{ }^{\circ} \mathrm{C}$ for $30 \mathrm{~s}$, annealing at $62{ }^{\circ} \mathrm{C}$ for $30 \mathrm{~s}$ and extension at $72{ }^{\circ} \mathrm{C}$ for $1 \mathrm{~min}$, followed by a final extension step at $72{ }^{\circ} \mathrm{C}$ for $10 \mathrm{~min}$.

In order to investigate the nucleotide sequence variability in the ovine IGF-I gene, restriction enzyme HaeII were selected according to their ability to digest
theDNA. The PCR product (265 bp) was digested with this enzyme for overnight at $37{ }^{\circ} \mathrm{C}$. After ethidium bromide staining, the gels were photographed under UV light and the DNA bands were evaluated. PopGene 3.1 was used for allele and genotype frequencies.

\section{Results and Discussion}

We determined three genotypes as the result of the restriction by HaeII enzyme; aa (179, 86 bp), bb (265 bp) and ab (265, 179, 86 bp) (Figure 2 and 3). Alleles found in this study were similar to those previously identified and reported by Yilmaz et al. (2005). Yilmaz et al. (2005) identified two single nucleotide polymorphisms; A and T to $\mathrm{C}$ transition at position 179.

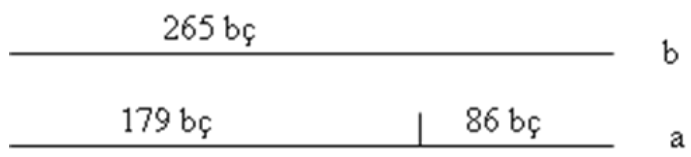

Figure 2

The digestion patterns of IGF-I with HaeII restriction enzyme.

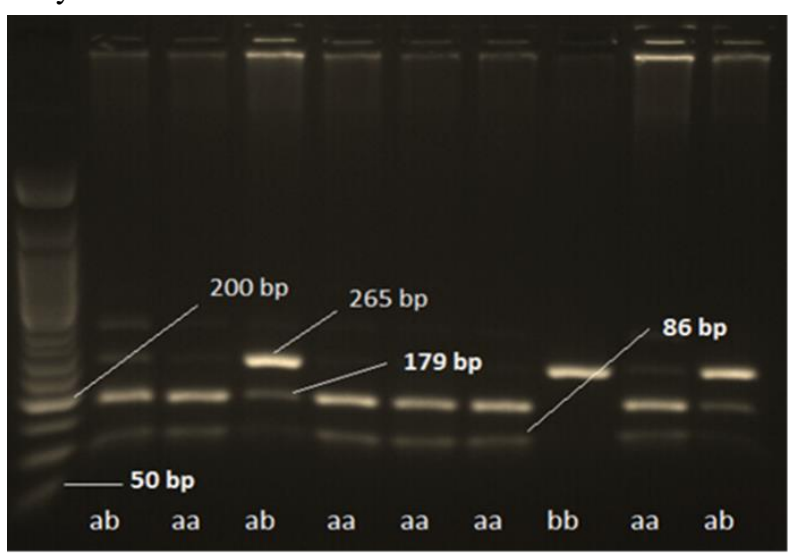

Figure 3

Digestion of the PCR amplified IGF-I gene with HaeII, First lane: 50 bp ladder; lane 2-4-10: ab genotype; lane 3-5-6-7-9: aa genotype; lane 8: bb genotyp

Table 1

The allele and genotype frequencies for IGF-I gene as digestedbyHaeII restriction enzyme

\begin{tabular}{llllllll}
\hline \multirow{2}{*}{ Breed } & $\mathrm{N}$ & \multicolumn{2}{c}{ Genotype frequencies $(\%)$} & \multicolumn{3}{c}{ Allelefrequencies $(\%)$} \\
\cline { 3 - 8 } & & $\mathrm{Aa}$ & $\mathrm{Ab}$ & $\mathrm{bb}$ & $\mathrm{a}$ & $\mathrm{B}$ & $\chi^{2}$ \\
\hline Karayaka & 19 & 79.00 & 10.50 & 10.50 & 0.84 & 0.16 & $8.42^{* *}$ \\
Daglic & 18 & 75.00 & 12.50 & 12.50 & 0.81 & 0.19 & $4.31^{*}$ \\
Awassi & 15 & 23.07 & 53.86 & 23.07 & 0.50 & 0.50 & 0.18 \\
Sakiz & 17 & 60.00 & 33.30 & 6.67 & 0.77 & 0.23 & 0.16 \\
\hline
\end{tabular}


Table 1

The allele and genotype frequencies for IGF-I gene as digestedbyHaeII restriction enzyme

\begin{tabular}{|c|c|c|c|c|c|c|c|}
\hline Kivircik & 16 & 75.00 & 12.50 & 12.50 & 0.81 & 0.19 & $6.80^{* *}$ \\
\hline Akkaraman & 19 & 68.75 & 6.25 & 25.00 & 0.72 & 0.28 & $12.75^{* *}$ \\
\hline Morkaraman & 20 & 13.30 & 46.70 & 40.00 & 0.37 & 0.63 & 0.013 \\
\hline Malya & 20 & 70.59 & 11.76 & 17.65 & 0.76 & 0.24 & $8.86^{* *}$ \\
\hline Allbreeds & 144 & 58.80 & 22.7 & 18.50 & 0.70 & 0.30 & $25.51^{* *}$ \\
\hline
\end{tabular}

$* \mathrm{P}<0.05 ; * * \mathrm{P}<0.01$

Allele $b$ obtained from the digestion of IGF-I with HaeII was found more frequent in the Morkaraman breed. Allele a wasfound more frequent in all the other breeds. The HW test showed that the studied Awassi, Sakiz and Morkaraman breeds fit the theoretical proportions. However, Karayaka, Daglic, Kivircik, Akkaraman and Malya don't fit the theoretical proportions for the HaeII digestions of this gene $(\mathrm{P}<0.05$; $\mathrm{P}<0.01)$ (Table 1).

This research is the first investigation of detecting the polymorphism of IGF-I gene with HaeIIrestriction enzyme in Turkishnativesheep breeds. Two allells and three genotypes were observed when RFLP markers performed to detect the polymorphisms of promoter regionof IGF-I.

\section{Conclusion}

Meat production of Turkey cannot meet the demand. Therefore, priority should be given to breeding studies aimed forincreasing the meat yield of the existing animals. The relationship between the meat yield and IGF-I genes in sheep has been demonstrated by many studies in the world. Turkey doesn't have enough information about this gene region. In this study, considering the lack of information on some of the sheep breeds raised in Turkey we havetried to reveal polymorphism of the IGF-I gene. There are very few studies in sheep breeds of Turkey on this subject. Therefore, this study in terms of revealing the genotypes for the IGF-I gene in the Turkish sheep populations is a pioneer study. When the genotypes have been determined, it will be possible to select them by using this gene region in the sheep by revealing the relationship between the sequence studies and the yield.

\section{Acknowledgement}

This study was performed by Mustafa Tawfeeq in partial fulfilment of the master degree in Biometry and Genetics, Animal Science Dept., Selcuk University. This project was supported by a grant from The Scientific Research Project Coordinating Office of Selcuk University (Project No: 17201120).

\section{References}

Alakilli SY,Mahrous KF, Salem LM, Ahmed ES (2012). Genetic polymorphism of five genes associated with growth traits in goat, African Journal of Biotechnology, 11 (82): 14738-14748.

Ali A, Javed K, Akram M, Dawood M, Saleem A. (2016). Polymorphism of insulın-like growth factor-1 gene and its association with growth rate in desi chicken of Pakistan, JAPS, Journal of Animal and Plant Sciences, 26 (3): 858-861.

Behzadi S, Miraei-Ashtiani SR, Sadeghi M, Zamani P, Abdoli R (2015). Association of IGF-I gene polymorphisms with carcass traits in Iranian Mehraban sheep using SSCP analysis, Iran. J. Appl. Anim. Sci., 5: 121-126.

Bondy CA, Underwood LE, Clemmons DR, Guler HP, Bach MA, Skarulis M (1994). Clinical uses of insulin-like growth factor I, Annals of internal medicine, 120(7): 593-601.

Ge W, Davis ME, Hines HC, Irvin KM. Simmen RC (2001). Association of a genetic marker with blood serum insulin-like growth factor-I concentration and growth traits in Angus cattle, J. Anim. Sci., 79: 1757-1762.

Grochowska E, Borys B, Janiszewski P, Knapik J. Mroczkowski S (2017). Effect of the IGF-I gene polymorphism on growth, body size, carcass and meat quality traits in Coloured Polish Merino sheep. Archives Animal Breeding, 60 (2): 161-173.

He J, Zhang B, Chu M, Wang P, Feng T, Cao G, Di R, Fang L, Huang D. Tang Q(2012). Polymorphism of insulin-like growth factor 1 gene and its association with litter size in Small Tail Han sheep, Molecular biology reports, 39 (10): 9801-9807.

Daughaday WH (1997). Sulfation factor revisited: The one-two punch of insulin-like growth factor-I action on cartilage. The Journal of laboratory and clinical medicine, 4(129): 398-399.

Kaymakci M, Engindeniz S (2010). Türkiye'de KeçiYetiştiriciliği: Sorunlar ve Çözümler. Ulusal Keçicilik Kongresi 24-26 Haziran 2010, Bildiriler Kitab1, Çanakkale, 1-25.

Kopchick JJ, List EO, Kelder B, Gosney ES, Berryman DE (2014). Evaluation of growth hormone (GH) action in mice: discovery of GH receptor antagonists 
and clinical indications, Molecular and cellular endocrinology, 386 (1-2): 34-45.

Le Roith D, Bondy C, Yakar S, Liu JL, Butler A (2001). The somatomedin hypothesis: Endocrine reviews, 22 (1): 53-74.

Li H F, Zhu WQ, Chen KW, Wu X, Tang QP,Gao YS (2008). Associations between GHR and IGF-1 gene polymorphisms, and reproductive traits in Wenchang chickens, Turkish Journal of Veterinary and Animal Sciences, 32 (4): 281-285.

Miller SA, Dykes DD, Polesky HF(1988). A simple salting out procedure for extracting DNA from human nucleated cells. Nucleic Acids Research, 16 (3): 1215.

Othman OE, Abdel-Samad MF, El-Maaty NAA (2016). Evaluation of insulin-like growth factor-I gene polymorphism in Egyptian small ruminant breeds, African Journal of Biotechnology, 15 (48): 2714-2719.

Pereira AP, Alencar MM, Oliveira HN, Regitano LC (2005). Association of GH and IGF-1 polymorphisms with growth traits in a synthetic beef cattle breed, Genetics and Molecular Biology, 28 (2): 230-236.

Siadkowska E, Zwierzchowski L, Oprzadek J, Strzalkowska N, Bagnicka E, Krzyzewski J(2006). Effect of polymorphism in IGF-1 gene on production traits in Polish Holstein-Friesian cattle, AnimSci Pap Rep, 24 (3): 225-237.

Yilmaz A, Davis ME, Hines HC, Chung H (2005). Detection of two nucleotide substitutions and putative promoters in the 5'flanking region of the ovine IGF-I gene, J Appl Genet, 46 (3): 307-309 